COMMENT

ZOOS' PRINT JOURNAL 20(5): 1879

\section{COMMENTS ON "AVIFAUNA OF THRISSUR DISTRICT, KERALA, INDIA" BY JAYSON ET AL.}

\section{Sashikumar}

9,Subhash Nagar, Kannur, Kerala 670 002, India

Email: csashikumar@rediffmail.com

I am writing this letter with regard to the paper published in the Zoos' Print Journal, February 2005 titled "Avifauna of Thrissur District, Kerala, India" by Jayson E.A. and C.I. Sivaperuman and would like to point out certain inaccuracies in the paper concerning certain species of birds listed.

1. Masked Booby Sula dactylatra: This is a pelagic bird, which reaches our coast and occasionally inlands during monsoon gales. This has been classified as a migrant in this paper

2. Spot-billed Pelican Pelecanus philippensis: As far as I know, there was only a single record of this species from the Kole (Ravindran, 1995). Obviously this species is a straggler and not a resident of the area.

3. Ferruginous Pochard Aythya nyroca: Details of the sightings of this species is not given; as far as Kerala is concerned, this species is extremely rare, with no recent sightings, though it is included in Birds of Kerala (Ali, 1969).

4. Jungle Bush-Quail Perdicula asiatica: Shown as present at KFRI Campus, KAU Campus and Peechi-Vazhani Sanctuary. The habitat of this bird is dry scrub (e.g. Chinnar Wildlife Sanctuary) and this species is unlikely to be seen at the above-mentioned places. More details desirable.

5. Wood Snipe Gallinago nemoricola and Woodcock Scolopax rusticola: Shown as seen at the Kole wetlands. Both are birds of damp areas in the forest with very few recent sightings; unlikely to be seen in Kole wetlands.

6. Spoon-billed Sandpiper Calidris pygmeus: Area seen not specified. This is one of the most endangered waders and the whole of the west coast has only one record (Uthaman \& Namassivayn, 1991). More details wanted.

7. Indian Courser Cursorius coromandelicus: No records from Kerala for the last several years and its habitat 'bare wasteland with scattered scrub' hardly exists here.

8. Lesser Black-backed Gull Larus fuscus: This species has been deleted from the Indian list (Grimmett et al., 1998; Kazmierczak, 2000; Manakkadan \& Pittie, 2001).

9. Tree Pipit Anthus trivialis: Shown as seen in the Kole wetlands. This species is found in 'well shaded plantations of tea, coffee and cardamom' above 900m (Ali, 1969).

10. Common Babbler Turdus caudatus: Shown as occurring in the Kole wetlands!!! This is the most 'uncommon babbler' of Kerala and has to be deleted from the state list, as there is no suitable habitat for it.

11. Bengal Bushlark Mirafra assamica: The Bushlark occurs in the Gangetic plain to Arunachal Pradesh, Manipur and Burma. The species we have here in southern India is Jerdon's Bushlark Mirafra affinis.
12. Plain Martin Riparia paludicola: Reported first in Kerala from the Kole wetlands by V. Santharam (Neelakantan et al., 1993). Here, it is shown as occurring in Peechi-Vazhani Wildlife Sanctuary.

Some other species, which according to this paper, said to occur in the Kole wetlands also need to be explained with more details. They are: Eurasian Sparrowhawk Accipiter nisus, Pallid Harrier Circus macrourus, Grey Francolin Francolinus pondiceranus, Eurasian Collared Dove Streptopelia decaocta, Small Sunbird Nectarinia minima, White-bellied Drongo Dicrurus caerulescens etc. Interestingly, the authors have omitted some of the most significant sightings at the Kole, e.g. White-tailed Lapwing Vanellus leucurus, Grey-headed Lapwing Vanellus cinereus (Ravindran, 2001; Ravindran \& Nameer, 2001).

\section{REFERENCES}

Ali, S. (1969). Birds of Kerala. OUP, Delhi.

Grimmett, R., C. Inskipp and T. Inskipp (1998). Birds of the Indian Subcontinent. OUP, Delhi.

Kazmierczak, K. (2000). A Field Guide to the Birds of India, Sri Lanka,Pakistan, Nepal, Bhutan, Bangladesh and Maldives. Om Book Service, New Delhi.

Manakkadan, R. and A. Pittie (2001). Standardised common and scientific names of the Birds of the Indian Subcontinent. Buceros 6(1). Ravindran, P.K. (1995). The Kole Wetlands - an avian paradise in Kerala. Newsletter for Birdwatchers 35(1): 2-5.

Ravindran, P.K. (2001). Sighting of the White-tailed Lapwing Vanellus leucurus (Lichtenstein) in Thrissur District, Kerala. Journal of the Bombay Natural History Society 98(2): 279.

Ravindran, P.K. and P.O. Nameer (2001). Grey-headed Lapwing Vanellus cinereus (Blyth) (Family Charadriidae) in Kerala. Journal of the Bombay Natural History Society 98(3): 450.

Uthaman, P.K. and L. Namassivayam (1991). The birdlife of Kadalundi Estuary. Blackbuck 7(1): 3-11.

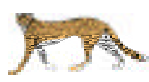

RESPONSE

ZOOS' PRINT JOURNAL 20(5): 1879-1880

\section{REPLY TO THE COMMENTS BY SASHIKUMAR ON "AVIFAUNA OF THRISSUR DISTRICT, KERALA, INDIA"}

\section{E.A. Jayson and C. Sivaperuman}

Division of Forest Ecology and Biodiversity Conservation, Kerala Forest Research Institute, Peechi, Thrissur, Kerala 680653, India Email: jayson@kfri.org

This is with reference to the comments made by Sashikumar on the Avifauna of Thrissur District, Kerala, India. The paper is a checklist compiled from our fieldwork and from published information collected from reports and research papers. We would like to point out that the bird species included in the Kole wetlands list include the sightings from different microhabitats like mud flats, shallow water, open water, bunds, floating vegetation, grasslands, canals and adjacent coconut and rubber plantations which is found in the Kole wetlands and adjacent areas.

1. Sula dactylatra: This species marked as Migrant (M) based on Ali and Ripley (1983).

(C) Zoo Outreach Organisation; www.zoosprint.org Response to comments received 22 March 2005; Edited and accepted 10 April 2005; Date of publication 21 April 2005 
2. Pelecanus philippensis: Recorded on 15.vi.1999 and 5.vii.1999 at Kanjany and status adopted from Ali and Ripley (1983). This species was also reported by Sreekumar (2004) from the Vembanad wetlands, which lies in the coast of Kerala.

3. Aythya nyroca: This species was recorded on 16.xi.1999 in Kanjany by the second author. Also reported by Kurup (1996) from the Purathur Estuary and Sreekumar (2004) from the Vembanad wetlands.

\section{Perdicula asiatica: Species identity needs confirmation.}

5. Gallinago nemoricola \& Scolopax rusticola: Recorded from Kanjany on 3.iii.1999 and 9.iii.1999, Enamavu on 23.iii.1999 on grasslands and marshy areas by the second author.

6. Calidris pygmeus: The species was not recorded or marked in any of the locations in the paper but came to the list by typographical error.

7. Cursorius coromandelucus: The species was not recorded or marked in any of the locations in the paper but came to the list by typographical error.

8. Larus fuscus: Reported by Nameer (1993) from Kole wetlands. Reported by Kurup (1996) from the Purathur Estuary and Sreekumar (2004) from the Vembanad wetlands.

9. Anthus trivialis: Recorded from Kanjany on 4.x.2000 and Parappur on 12.x.2000 on bunds by the second author.

10. Turdoides caudatus: Recorded from Kanjany on 5.x.1999, Pullu on 6.x.1999, Kanjany on 6.x.1999 on bunds and trees by the second author.

11. Mirafra assamica: Reported in Nameer et al. (2000) from the KAU campus.

12. Riparia paludicola: This species marked due to over site in the Peechi-Vazhani Wildlife Sanctuary, Recorded from the Kole wetland by Santharam (1995).

13. Accipiter nisus: Recorded from Enamavu on 17.xi.1998; 23.iii.1999; 26.iii.1999; 7.x.2001 by the second author.

14. Circus macrourus: Recorded from Parappur on 10.iii.1999; 22.ii.2001; Enamavu on 26.x.1999; Arimpur on 20.ii.2001 by the second author.

15. Francolinus pondicerianus: Recorded at Parappur on 3.viii.2001 in bushes in the coconut plantations adjacent to the Kole wetlands by the second author.

16. Streptopelia decaocta: Sighted from Kanjany on 28.iv.1999; 5.vii.2001; Punnayurkulam on 7.x.1999; Parappur on 9.xii.1999; on electric lines and on trees in the adjacent areas by the second author.

17. Nectarinia minima: Recorded from Parappur on 31.iii.2000 and 29.ix.2001 on trees adjacent to the Kole wetlands by the second author.

18. Dicrurus caerulescens: Recorded from Arimpur on 6.x.1999; 29.iii.2000; Alapatt on 6.xii.1999; Parappur on 17.xii.1999; 8.iii.2000; 31.iii.2000; Kanjany on 22.ii.2000; 27.iii.00; 27.iii.2000; 6.vii.2001 on electric lines by the second author.

REFERENCES

Ali, S. \& S.D. Ripley (1983). Hand Book of the Birds of India and
Pakistan. Oxford University Press, Oxford, 737pp.

Kurup, D.N. (1996). Ecology of the birds of Bharathapuzha Estuary and survey of the coastal wetlands of Kerala. Kerala Forest and Wildlife Department, 59pp.

Nameer, P.O. (1993). Birds of Kole Wetlands Survey Report-II. Nature Education Society, Trichur (NEST) in Collaboration with Kerala Forest Research Institute, and Kerala Forest Department, 17pp.

Nameer, P.O., R. Nair, K.R. Anoop, S.G. Nair, R. Lekshmi and P. Radhakrishnan (2000). Birds of Kerala Agricultural University Campus, Thrissur. Zoos' Print Journal 15(4): 243-246.

Santharam (1995). The Grey throated (or) Plain Sand Martin Riparia paludicola Vieillot - a new bird for southern India. Journal of the Bombay Natural History Society 92(1): 122.

Sreekumar, B. (2004). Vembanad water bird count. Department of Forests and Wildlife and Kottayam Nature Society, 42pp.

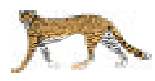

COMMENT

ZOOS' PRINT JOURNAL 20(5): 1880-1881

\section{COMMENTS ON "AVIFAUNA OF THRISSUR DISTRICT, KERALA, INDIA" BY E.A. JAYSON ET AL. (2005)}

\section{J. Praveen}

14/779(2), Ambadi, Kunnathurmedu P.O., Palakkad, Kerala 678013, India

Though late, having had a chance to go through the article "Avifauna of Thrissur District, Kerala, India" by Jayson and Sivaperuman in Zoos' Print Journal 20(2): 1774-1783, I felt a need for a clarification note as an addendum to the checklist. The picture painted by the article is incomplete and mostly erroneous. Here I tabulate a list of species from their checklist that I felt had erroneous information.

Most of the species on which I have commented are common ones and even beginner bird watchers are aware of the status of these birds (eg. Ashy Drongo). I have refrained from commenting on several tall claims in the checklist like the Spoonbilled Sandpiper (Calidirs pygmeus) or the Wood Snipe (Gallinago nemoricola). Considering the nature of basic mistakes interspersed over the length of the article (more than $10 \%$ of the species listed have wrong information), it is not unsafe to assume that the whole checklist has been prepared without sufficient groundwork. It is hoped that such publications don't get accepted in the future without sufficient reviews by people familiar with the avifauna of the region.

\section{REFERENCES}

Grimmett, R., C. Inskipp \& T. Inskipp (1998). Birds of the Indian Subcontinent. Christopher Helm, London.

Kazmierczak, K. (2000). A Field Guide to the Birds of India, Sri Lanka, Pakistan, Nepal, Bhutan, Bangladesh and the Maldives. Om Book Service, New Delhi.

Neelakantan, K.K., C. Sashikumar and R. Venugopal (1993). A Book of Kerala Birds. WWF, Kerala State Committee, Trivandrum.

Rajeevan, P.C., Suraj and C. Sashikumar (2004). Grey Heron Ardea cinerea breeding in Kerala, India. Newsletter for Ornithologists 1(6): 87 Raveendran, P.K. (1994). Gadwall at Kadalundy Estuary, Kerala. Newsletter for Birdwatchers 34(2): 33

(C) Zoo Outreach Organisation; www.zoosprint.org Comments received 24 March 2005; Edited and accepted 26 March 2005; Date of publication 21 April 2005 